\title{
The environment of the nursing team's professional practice in inpatient units of a university hospital
}

\author{
Ambiente da prática profissional da equipe de enfermagem em \\ unidades de internação de hospital universitário
}

Entorno de la práctica profesional del equipo de enfermería en unidades de hospitalización de un hospital universitario

\section{Ana Maria Müller de Magalhães ${ }^{a}$ Débora Rosilei Miquini de Freitas Cunha ${ }^{a, b}$ Gisela Maria Schebella Souto de Moura ${ }^{a}$ (ID Janete de Souza Urbanettoc Wiliam Wegner ${ }^{\mathrm{a}}$ João Lucas Campos de Oliveira ${ }^{\mathrm{a}}$}

\section{How to cite this article:} Magalhães AMM, Cunha DRMF, Moura GMSS, Urbanetto JS, Wegner W, Oliveira JLC. The environment of the nursing team's professional practice in inpatient units of a university hospital. Rev Gaúcha Enferm. 2020;41:e20190460. doi: https://doi.org/10.1590/19831447.2020.20190460
Universidade Federal do Rio Grande do Sul (UFRGS), Escola de Enfermagem, Programa de Pós-Graduação em Enfermagem. Porto Alegre, Rio Grande do Sul, Brasil.

${ }^{6}$ Hospital de Clínicas de Porto Alegre (HCPA), Porto Alegre, Rio Grande do Sul, Brasil.

Pontificia Universidade Católica do Rio Grande do Sul (PUCRS), Faculdade de Enfermagem, Nutriçăo e Fisioterapia, Pós-Graduação em Gerontologia Biomédica. Porto Alegre, Rio Grande do Sul, Brasil.

\section{ABSTRACT}

Objective: To evaluate the environment of the professional practice of the nursing staff from inpatient units and to compare it according to professional and work characteristics.

Method: A cross-sectional analytical study conducted in southern Brazil. Data was collected through the Brazilian version of the Nursing Work Index-Revised with a sample of ( $n=142$ ) professionals, them being nurses ( $n=56 ; 34.9 \%)$ and nursing technicians/ assistants $(n=86 ; 60.6 \%)$. The analysis was performed by means of descriptive and analytical statistics

Results: The professional practice environment was considered favorable in all the subscales. The subscale of relationships between physicians/nursing staff showed a significant difference among the professional categories, with better results for nurses. The afternoon shift stood out in the favorable assessment. Longer working time at the institution and unit tended to have worse assessments for autonomy and control, respectively.

Conclusion: The assessment of the practice environment was favorable; however, the study signals opportunities for improvements for the nursing team.

Keywords: Health facility environment. Patient safety. Quality of health care. Nursing administration research. Nursing

\section{RESUMO}

Objetivo: Avaliar 0 ambiente da prática profissional da equipe de enfermagem de unidades de internaç̃̃o hospitalar e compará-lo segundo características profissionais e do trabalho.

Método: Estudo transversal, analítico, realizado no sul do Brasil. Os dados foram coletados por meio da versão brasileira do Nursing Work Index-Revised a amostra ( $n=142)$ de profissionais, enfermeiros $(n=56 ; 34,9 \%)$ e técnicos/auxiliares de enfermagem ( $n=86 ; 60,6 \%)$. A análise deu-se por estatística descritiva e analítica.

Resultados: 0 ambiente da prática profissional foi considerado favorável em todas as subescalas. A subescala relacões entre médicos/ equipe de enfermagem apresentou diferença significante entre categorias profissionais, com melhor resultado para enfermeiros. 0 turno da tarde destacou-se na avaliação favorável. Maior tempo de trabalho na instituição e na unidade apresentaram tendência de piores avaliações para autonomia e controle, respectivamente.

Conclusão: A avaliação do ambiente de prática foi considerada favorável, no entanto o estudo aponta oportunidades de melhorias para a equipe de enfermagem.

Palavras-chave: Ambiente de instituições de saúde. Segurança do paciente. Qualidade da assistência à saúde. Pesquisa em administração de enfermagem. Enfermagem.

\section{RESUMEN}

Objetivo: Evaluar el entorno de práctica profesional del personal de enfermería de las unidades de hospitalización y compararlo según las características profesionales y laborales.

Método: Estudio analítico y transversal realizado en el sur de Brasil. Los datos se recolectaron a través de la versión brasileña de del índice de trabajo de enfermería con una muestra de $(n=142)$ profesionales: enfermeras $(n=56 ; 34,9 \%)$ y técnicos/asistentes de enfermería ( $n=86 ; 60,6 \%)$. El análisis fue por estadística descriptiva y analítica.

Resultados: El entorno de la práctica profesional fue favorable en todas las subescalas. Las subescala de relaciones entre médicos/ personal de enfermería presentó una diferencia significativa entre las categorías profesionales, con mejores resultados para las enfermeras. El turno de la tarde se destacó en la evaluación favorable. El tiempo de trabajo más prolongado en la institución y/o en la unidad se asociaron con una tendencia a obtener peores evaluaciones de autonomía y control, respectivamente.

Conclusión: La evaluación del entorno de la práctica fue favorable; sin embargo, el estudio señala oportunidades de mejora para el equipo de enfermería.

Palabras clave: Entorno de instituciones de salud. Seguridad del paciente. Calidad de la atención de la salud. Investigación en administración de enfermería. Enfermería. 


\section{口INTRODUCTION}

The nursing work environment is an expression used internationally to define a set of concrete and abstract organizational characteristics that facilitate or limit the professional practice of the category in order to deliver high-quality nursing care $\mathrm{e}^{(1-2)}$

Researchers have identified that certain attributes such as professional autonomy, control over the nurse's professional practice, professional, and cordial relationships among physicians and nurses, and organizational support are important elements for the construction of a favorable or unfavorable environment to the nursing team's practice and that this tends to impact on the care quality and on patient safety ${ }^{(3-5)}$.

In the hospital setting, enhancements in the nursing practice environment can be an organizational strategy, contributing to the improvement of the care provided to the patient, who is naturally exposed to many risks ${ }^{(4)}$. Thus, for decades, studies on the nursing team's professional practice environment have been valued, for, if favorable, they direct better results to the professionals, health institutions, and patients $s^{(2,6)}$.

The current scenario of the health organizations, and especially hospitals, requires continuous improvement of management processes and qualification of professionals. In this sense, the constant search for favorable work environments is a way of valuing the nursing professionals, investing in their development and interest in staying in the job ${ }^{(5)}$.

The process of working in hospital nursing involves daily complex decisions and attitudes that ensure viability of $\operatorname{care}^{(7)}$. In the perspective of contextualizing this theme, many studies were conducted with the objective of identifying and analyzing the professional practice environment of the nursing team and how much it can affect care quality ${ }^{(4,6,8-9)}$.

Despite the increasing number of studies on this theme, there are still gaps about how much the characteristics of the professional practice environment can affect the results of care quality and patient safety ${ }^{(10)}$. Especially in the Brazilian scenario, developing studies that may identify organizational factors capable of impacting these indicators is considered to be pertinent, aiming to subsidize the decision-making processes of the management in the continuous search for improvement of the processes and better working conditions for the nursing team.

One of the possibilities to assess the work environment in hospital facilities is the use of instruments capable of measuring the objective aspects, which can influence job satisfaction and interfere with care quality and patient safety ${ }^{(11)}$. Among the available instrument in the literature, the Nursing Work Index - Revised (NWI-R) stands out, which was developed ${ }^{(3)}$ in the American context, but has been used in different cultures and environments of the nursing team's professional practice since then, like China, France, Italy, and Germany, among others ${ }^{(1)}$.

In Brazil, the instrument in question was validated initially for nurses ${ }^{(12)}$ and later for nursing technicians and assistants, and was called Brazilian-Nursing Work Index-Revised - B-NWI-R ${ }^{(13)}$. This is interesting and necessary because Brazilian nursing is hierarchical, and, thus, analyzing the practice environment considering distinct professional categories is valuable, as it can be a factor that contributes to more assertive decisions and improvement in the professional practice environment.

Considering the arguments listed and the practice environment an essential factor for the development of the nursing work and for patient safety, this study seeks to answer the following questions: What is the assessment of the nursing team in hospital inpatient units regarding their professional practice environment? Are there differences in the assessment of the nursing work environment according to professional and work characteristics? So, the objective was to assess the professional practice environment of the nursing team in hospital inpatient units and to compare it among professional categories and work shifts.

\section{METHOD}

This is a cross-sectional, descriptive, and analytical study. It was carried out in a large public university hospital, located in the southern region of the country and accredited by the Joint Commission International since $2013^{(14)}$. The field research took place from August to December 2018, in 13 clinical and surgical inpatient units for adults, which account for 425 beds.

The population consisted of all $(n=562)$ the nursing professionals working in these units in the period. For sample calculation a 95\% significance level was adopted, with an error margin of 0.2 points, considering the result of the previous study, in which the lowest mean score of a B-NWI-R subscale was $1.9(\mathrm{SD}=0.71)^{(15)}$. With these parameters, a sample estimate of 57 professionals per category was obtained, i.e., 114 professionals. Adding 10\% for possible losses or refusals, the sample size was estimated at 126 subjects, 63 nurses, and 63 elementary and high school nursing professionals.

There were 142 professionals in the sample studied, 56 of whom were nurses and 86, nursing technicians/assistants. The selection of the participants was through random sampling in which the eligible professionals were numbered in a sequence and a draw was done at the unit, with the presence of the nurse; the first professional of the scale was drawn and then, followed by an interval of two professionals for inclusion in the sample. 
The inclusion criteria were the following: nurses working at the referred units, acting in the practice environment for at least 90 days, and who directly assist the patient. The exclusion ones were the following: professionals under a hiring contract of less than 90 days, on vacation or on leave for any reason in the data collection period, in addition to the professionals that do not directly care for the hospitalized patient. A total of 26 losses were accounted for, from instruments with three or more non-answered questions, apart from eight refusals to answer data collection, corresponding to an $80.7 \%$ response rate.

Data collection occurred by means of a sociodemographic and professional characterization questionnaire, and by means of the B-NWI-R instrument, in the version for nurses and nursing technicians/assistants, which is composed of 15 items distributed into four subscales: five items on autonomy; seven items on control over the work environment; three items on relationships between the physicians and the nursing team; and ten items on organizational support, grouped from the three previous subscales. The scale is a Likert-type one, composed of four points, namely: "I totally agree (1)"; "I partially agree (2)"; "I partially disagree (3)" and "I totally disagree (4)", with a result varying from one to four points ${ }^{(3,12)}$.

The B-NWI-R scores are obtained by the mean values of the participants'answers in each subscale. The cut-off point of 2.5 was defined to consider favorable environments so, the lower the score, the greater the presence of attributes favorable for the professional practice. Values above 2.5 points represent unfavorable environments ${ }^{(15)}$. Authorization was requested and obtained from the authors who adapted the instruments to the Brazilian context.

After digital tabulation, data was analyzed in the Statistical Package for the Social Sciences (SPSS) program, version 21.0, from a database organized in the 2010 Microsoft Office Excel. The symmetric continuous variables were described by mean and standard deviation, and the asymmetric variables by median and interquartile range. The categorical variables were described with absolute and relative frequencies.

For the comparison of the continuous, sociodemographic, and professional variables, the Student's t-, Mann-Whitney, and Pearson's chi-square tests were used. To evaluate the association between the continuous and ordinal variables among the professional categories (nurses and mid-level workers), Pearson's correlation test was employed for the variables with normal distribution, and the Spearman's correlation coefficient, for the variables with an asymmetric distribution. For analysis and comparison of means of assessment of the practice environment between the shifts, analysis of variance (ANOVA) was used. A significance level of $5 \%$ was considered ( $p$-value $\leq 0.05$ ). The Cronbach Alpha test was used to evaluate the internal consistency of the instrument in the studied sample, obtaining a satisfactory value in the total of the instrument (Cronbach's alpha $=0.861$ ), and it remained above 0.7 in all the subscales.

This study was approved by the Ethics Committee of the institution under opinion number 2,535,834. Thus, the standards of Resolution No. 466 (2012) of the National Health Council for research projects involving human beings were met.

\section{RESULTS}

The sample surveyed was characterized by the predominance of female professionals ( $n=117 ; 82.4 \%$ ). The mean age was $40.6+7.7$ years old among nurses and $42.7+9.1$ among nursing technicians and assistants. Regarding schooling, seven $(12,5 \%)$ nurses had only an undergraduate degree, the others had specializations, masters, or $\mathrm{PhD}$ degrees. Among the nursing technicians/assistants, 11 (12.8\%) had an undergraduate degree and three (3.5\%) had a specialization degree.

The median of the working time of the professionals in the institution was 10 years (5-16), while the median of the working time in the unit was 6 years (3-11), the latter being significantly higher in nursing technicians/assistants $(p=0.026)$. Most of the participants had no other employment contract $(90.8 \%)$ and the work shift was evenly distributed among the professionals. Other data related to the sample's sociodemographic and labor characteristics are shown in Table 1.

The mean scores in the B-NWI-R subscales varied between $1.82+0.54$ and $2.05+0.62$, in the total sample. An assessment of the practice environment below 2.5 in all sub-scales of the instrument is verified, both for nurses and for nursing technicians/assistants.

Table 2 shows the descriptive analysis of the B $-N W I-R$ subscales between nurses and nursing technicians, as well as the inferential comparison between these professional categories. A significant difference $(p<0.002)$ is identified in the assessment of the subscale of relationships between physicians, nurses, and nursing team among the categories of the nursing professionals.

The correlations found between the variables of age, schooling level, and working time in the institution and in the unit with the B-NWI-R subscales were weak and significant in some cases, such as age, autonomy, and schooling level with the subscales of control and physician-nursing team relationship, working time in the institution, and autonomy, in addition to between working time in the unit and control. These and other data are shown in Table 3. 
Magalhães AMM, Cunha DRMF, Moura GMSS, Urbanetto JS, Wegner W, Oliveira JLC

Table 1 - Sociodemographic and work characteristics of the sample of nurses, nursing assistants and technicians. Porto Alegre, RS, Brazil, 2018

\begin{tabular}{|c|c|c|c|c|}
\hline Variables & $\begin{array}{c}\text { Total } \\
\text { Sample } \\
(n=142)\end{array}$ & $\begin{array}{c}\text { Nurses } \\
(n=56 ; 39.4 \%)\end{array}$ & $\begin{array}{c}\text { Assistants/ } \\
\text { Technicians } \\
\text { (n=86; 60.6\%) }\end{array}$ & p-value \\
\hline $\mathrm{Age}^{*}$ & $42.0 \pm 8.7$ & $40.6 \pm 7.7$ & $42.7 \pm 9.1$ & $0.195^{\#}$ \\
\hline \multicolumn{5}{|l|}{ Gender** } \\
\hline Male & $25(17.6)$ & $4(7.1)$ & $21(24.4)$ & \multirow{2}{*}{$0.016^{\# \#}$} \\
\hline Female & $117(82.4)$ & $52(92.9)$ & $65(75.6)$ & \\
\hline \multicolumn{5}{|l|}{ Schooling** } \\
\hline High School/Elementary & $72(50.7)$ & - & $72(83.8)$ & \multirow{5}{*}{$<0.001^{ \pm}$} \\
\hline Graduation & $18(12.7)$ & $7(12.5)$ & $11(12.8)$ & \\
\hline Specialization & $39(27.5)$ & $36(64.3)$ & $3(3.5)$ & \\
\hline Master's degree & $11(7.7)$ & $11(19.6)$ & - & \\
\hline $\mathrm{PhD}$ & $2(1.4)$ & $2(3.6)$ & - & \\
\hline \multicolumn{5}{|l|}{ Working Time } \\
\hline In the institution & $10(5-16)$ & $7(4-13)$ & $10(6-15)$ & $0.053^{\# \#}$ \\
\hline In the Unit & $6(3-11)$ & $5(3-7)$ & $7(4-14)$ & $0.026^{\# \#}$ \\
\hline \multicolumn{5}{|c|}{ Other employment contract** } \\
\hline Yes & $13(9.2)$ & $6(10.7)$ & $7(8.1)$ & \multirow{2}{*}{$0.824^{ \pm}$} \\
\hline No & $129(90.8)$ & $50(89.3)$ & 79 (91.9) & \\
\hline \multicolumn{5}{|l|}{ Shift ${ }^{* *}$} \\
\hline Morning & $38(28.1)$ & $15(30.0)$ & $23(27.1)$ & \\
\hline Afternoon & $52(38.5)$ & $22(44.0)$ & $30(35.3)$ & $0.368^{ \pm}$ \\
\hline Night & $45(33.3)$ & $13(26.0)$ & $32(37.6)$ & \\
\hline
\end{tabular}

Source: Research data, 2018.

${ }^{*}$ mean \pm standard deviation, ${ }^{* *} n(\%)$ and median (percentiles 25-75), \# Student's t-test, \#\#Mann-Whitney's test, \pm Pearson's chi-square test.

Finally, Table 4 summarizes the findings of the assessment of the nursing practice environment in relation to work shifts. The professionals who work in the afternoon shift had a better perception of the work environment in the autonomy, control, and organizational support subscales than those from other shifts, with significant differences of $p=0.016$, $p=0.001$, and $p=0.005$, respectively. For the physician-nursing team relationships, the differences between shifts were not statistically significant. 
Table 2 - Means of the B-NWI-R scores for nurses, nursing assistants and technicians, and comparison between professional categories. Porto Alegre, RS, Brazil, 2018

\begin{tabular}{|c|c|c|c|c|}
\hline \multirow[t]{2}{*}{ Subscales } & $\begin{array}{l}\text { Total Sample } \\
(n=142)\end{array}$ & $\begin{array}{l}\text { Nurses } \\
(\mathrm{n}=56)\end{array}$ & $\begin{array}{c}\text { Assistants/ Technicians } \\
(\mathbf{n}=\mathbf{8 6})\end{array}$ & \multirow[t]{2}{*}{ p-value" } \\
\hline & Mean \pm SD & Mean \pm SD & Mean \pm SD & \\
\hline Autonomy & $1.82 \pm 0.54$ & $1.78 \pm 0.46$ & $1.85 \pm 0.59$ & 0.505 \\
\hline Control over the environment & $1.96 \pm 0.50$ & $1.86 \pm 0.47$ & $2.02 \pm 0.51$ & 0.075 \\
\hline $\begin{array}{l}\text { Physician-nurse/nursing } \\
\text { team relationships }\end{array}$ & $2.05 \pm 0.62$ & $1.86 \pm 0.49$ & $2.18 \pm 0.67$ & 0.002 \\
\hline Organizational support & $1.91 \pm 0.49$ & $1.82 \pm 0.42$ & $1.98 \pm 0.52$ & 0.061 \\
\hline
\end{tabular}

Source: Research data, 2018

*-Student's t Test

Table 3 - Correlation between the B-NWI-R subscales with sociodemographic and work variables. Porto Alegre, RS, Brazil, 2018

\begin{tabular}{|c|c|c|c|c|}
\hline Variables & Age & Schooling level & $\begin{array}{l}\text { Working time in } \\
\text { the institution }\end{array}$ & $\begin{array}{l}\text { Working time in } \\
\text { the unit }\end{array}$ \\
\hline Autonomy & $\begin{array}{l}r=0.189 \\
(p=0.034)\end{array}$ & $\begin{array}{l}r_{s}=-0.085 \\
(p=0.312)\end{array}$ & $\begin{array}{l}r_{s}=0.214 \\
(p=0.014)\end{array}$ & $\begin{array}{l}r_{s}=0.132 \\
(p=0.133)\end{array}$ \\
\hline Control & $\begin{array}{l}r=0.165 \\
(p=0.063)\end{array}$ & $\begin{array}{l}r_{s}=-0.178 \\
(p=0.034)\end{array}$ & $\begin{array}{l}r_{s}=0.130 \\
(p=0.137)\end{array}$ & $\begin{array}{l}r_{s}=0.181 \\
(p=0.039)\end{array}$ \\
\hline $\begin{array}{l}\text { Physician-nurse/ } \\
\text { nursing relationship }\end{array}$ & $\begin{array}{l}r=-0.013 \\
(p=0.883)\end{array}$ & $\begin{array}{l}r_{s}=-0.182 \\
(p=0.030)\end{array}$ & $\begin{array}{l}r_{s}=0.060 \\
(p=0.494)\end{array}$ & $\begin{array}{l}r_{s}=0.060 \\
(p=0.496)\end{array}$ \\
\hline Organizational support & $\begin{array}{l}r=-0.143 \\
(p=0.108)\end{array}$ & $\begin{array}{l}r_{s}=-0.186 \\
(p=0.027)\end{array}$ & $\begin{array}{l}r_{s}=0.169 \\
(p=0.053)\end{array}$ & $\begin{array}{l}r_{s}=0.152 \\
(p=0.083)\end{array}$ \\
\hline
\end{tabular}

Source: Research data, 2018

$r=$ Pearson's correlation coefficient: $r_{s}=$ Spearman's correlation coefficient

Table 4 - Means of the B-NWI-R scores, comparing by work shifts. Porto Alegre, RS, Brazil, 2018

\begin{tabular}{ccccc} 
Subscales & $\begin{array}{c}\text { Morning } \\
(\mathbf{n = 3 8 )}\end{array}$ & $\begin{array}{c}\text { Afternoon } \\
(\mathbf{n = 5 2 )}\end{array}$ & $\begin{array}{c}\text { Night } \\
(\mathbf{n = 4 5 )}\end{array}$ & p-valuet \\
\cline { 2 - 4 } & Mean \pm SD & Mean \pm SD & Mean \pm SD & \\
Autonomy & $1.99 \pm 0.51^{\mathrm{b}}$ & $1.67 \pm 0.43^{\mathrm{a}}$ & $1.87 \pm 0.65^{\mathrm{ab}}$ & $\mathbf{0 . 0 1 6}$ \\
Control & $2.13 \pm 0.50^{\mathrm{b}}$ & $1.75 \pm 0.46^{\mathrm{a}}$ & $2.04 \pm 0.48^{\mathrm{ab}}$ & $\mathbf{0 . 0 0 1}$ \\
Physician-nurse relationship & $2.11 \pm 0.69$ & $1.94 \pm 0.57$ & $2.18 \pm 0.63$ & 0.158 \\
Organizational support & $2.06 \pm 0.52^{\mathrm{b}}$ & $1.75 \pm 0.42^{\mathrm{a}}$ & $1.99 \pm 0.50^{\mathrm{b}}$ & $\mathbf{0 . 0 0 5}$ \\
\hline
\end{tabular}




\section{DISCUSSION}

The sample characterization was similar to other research studies ${ }^{(11-13)}$, with a predominance of female professionals, which is justified by the historical character of the profession. The mean age of the professionals is also highlighted, 42 years old, an age range ( $>41$ years old) different from that of other studies ${ }^{(11,16)}$, which present age means around 35 years old, a fact that leads us to presume that they are professionals with relevant life experience and, therefore, more mature; this can be a favorable point as for the decision-making processes, whether in the professional or in the work scope.

The schooling level data indicates that the majority of the nurses (87.5\%) have some qualification above undergraduate degree in Nursing, with specialization courses (64.3\%), masters (19.6\%) and PhDs (3.6\%). Among the nursing technicians/assistants, it is observed that $16.3 \%$ declares some qualification beyond the requirements to their professional practice, with undergraduate degrees and specializations. These data can be associated with the interest in progressing professionally and demonstrate an investment in qualification and personal improvement, a plausible characteristic of the survey institution, which avails spaces for professional ascension by means of financial incentives in the career scope for post-graduate studies, in addition to the concession of study hours and for participation in scientific events for professional improvement.

This data is important since a number of studies indicate significant effects of an adequate nursing staff, a favorable practice environment, and schooling levels among the nurses on care quality and patient mortality. These studies signal that the increased number of bachelor-degree nurses, or with a higher schooling level, was associated with the chance of a $9 \%$ reduction in patient mortality in inpatients units ${ }^{(6,17)}$.

This study demonstrates that the nursing team recognizes its professional practice environment as favorable in all the domains of the B-NWI-R instrument, as they presented results below 2.5 points, according to the established cut-off point, that is, the professionals considered that the characteristics of the practice environment were favorable regarding autonomy, control over the environment, good relations between physicians and nurses/nursing team, and organizational support. Similar data are described in studies conducted with the application of the same instrument in different areas of the nursing practice such as inpatients units, intensive therapy, and pediatrics in the Brazilian context ${ }^{(11,15,18)}$.

It is highlighted that, even presenting a favorable perception by the professionals, the "physician-nurse/nursing team relationships"subscale attained the highest score, that is, had the worst assessment among the four subscales of the instrument. When the two professional groups were compared, there was a significant difference $(p=0.002)$, indicating that the nurses' perception was more favorable than that of the nursing technician/assistants. This result signals the need for assessment and investment by the institution's management in the improvement of this characteristic in the practice environment, mainly when related to the mid-level professionals in their interactions with the physicians.

A similar result was found in another Brazilian study ${ }^{(16)}$ with a mean score in this subscale of $2.22+0.79$ and indicating that the relationship between physicians and nurses was significantly less favorable ( $p=0.03$ ) when comparing hospital nurses with those from primary health care and outpatient units. The authors also highlight that the practice environment was evaluated as favorable, except for the control over the environment subscale.

All the significant correlations found were considered weak ( $>0.3$ ), but indicate some associations that can be explored in future studies. Age and working time in the institution were directly and significantly associated with autonomy, indicating that the older the age and the longer the working time, the higher were the scores for this subscale, which means a worse assessment regarding autonomy in the practice environment. These characteristics of the sample's professionals point out to a stable and mature team that can perform greater analyses of the organizational processes and develop critical thinking, in the sense of claiming improvements in the work environment. In addition, it is considered that the stability of the nursing team is an important factor for the sustainability and maintenance of quality standards and patient safety.

A recent meta-analysis of studies on the nursing practice environment indicates that the nurses'schooling, as well as their retention by the institution, contributes to the best results in care and patient safety, as well as to the maintenance of a healthy environment for the professionals ${ }^{(19)}$.

The weak, inverse, and significant correlation between the schooling level and "the control over the environment" and "physician-nursing team relationships"subscales shows that the professionals with higher schooling levels have lower scores in these subscales, indicating a more favorable perception towards these characteristics of the practice environment. This finding corroborates with the other result found, of a worse assessment of the "physician-nursing team relations" subscale by the professional nursing technicians and assistants.

In other words, the study suggests that nurses appreciate more favorably their relationship with the medical team, which may perhaps be explained by the still visible distancing between physicians and the mid-level nursing team 
persisting in the hospital setting, given the rigid historical models of care management.

A research study conduct with 129 nursing professionals of 17 hospitals in the state of São Paulo attested that the professionals with not much autonomy, lower control over the environment, and with worse relationships with the physicians manifested worse care quality, more job dissatisfaction, and greater intention of leaving the job when mediated by the feeling of emotional exhaustion ${ }^{(15)}$. Therefore, considering the findings of the study and the correlated literature, we may infer that a better relationship of the nursing team with the physicians is a factor that deserves investment, which possibly transposes only the nursing leadership power, teamwork and cooperation among the interested ones being necessary.

Even with the favorable practice environment assessment in all the shifts (scores $<2.5$ ), it is worth highlighting the identification of the best perception of the practice environment in the autonomy, control over the environment, and organizational support subscales among the afternoon shift professionals, with significant differences for the other shifts. This finding can subsidize the comprehension of factors by the leaders that may be contributing to this result, even if we have not found other studies doing the same comparison among the work shifts.

The results of this study provide elements for assertive decision making in what concerns the favorable nursing practice environment. In this scope, a contribution from this study is the evidence of several differences in the perception of the professional practice environment among shifts, which reinforces that nursing managers need to immerse in the working process to understand, indeed, the aspects that can interfere with the positive or negative perceptions by the nursing professionals with regard to their performance and, with this, dialogically reasoning strategies that can enhance better perceptions, contributing to care quality and safety.

It is worth highlighting that new studies are necessary for broadening the data in order to design more robust statistical tests to evaluate the associations and correlations among the variables, in addition to the possible effects of the practice environment directly verified in the quality and safety of the care provided, which still seems to be a knowledge gap, especially in Brazil.

The limitations of the study are considered to be its cross-sectional design in a single institution, which does not allow for a generalization of its results. However, anchored in results from other national and international studies, it can contribute to strengthening Nursing as an essential element for accomplishing safe and quality results for the hospitalized patients.

\section{Q CONCLUSION}

The nursing work environment was evaluated in a favorable way by the nursing team. There were significant differences in the comparative evaluation, with the category of nurses and the afternoon shift receiving more positive assessments. Longer working times in the institution and in the unit were related to less favorable scores in the autonomy and control subscales, respectively.

The physician/nurse/nursing team relationship subscale proved to be a weak point to be evaluated, as it presented the highest scores, considered less satisfactory, especially among mid-level workers. This provides an opportunity to reflect on the relationships between the professional categories and a possible need to bring the medical team closer to the professionals who deal with a greater emphasis on direct care.

The findings of this investigation can contribute to improving the professional practice environment, providing the leaders with elements for the continuous search of healthy work environments and that produce high quality and reliability for the hospitalized patients.

\section{REFERENCES}

1. Swiger PA, Patrician PA, Miltner RS, Raju D, Breckenridge-Sproat S, Loan LA. The Practice Environment Scale of the Nursing Work Index: an updated review and recommendations for use. Int J Nurs Studies. 2017;74:76-84. doi: https://doi. org/10.1016/j.jpnurstu.2017.06.003

2. Lake ET. Development of the Practice Environment Scale of the Nursing Work Index. Res Nurs Health. 2002; 5(3):176-88. doi: https://doi.org/10.1002/nur.10032

3. Aiken $L H$, Patrician PA. Measuring organizational traits of hospitals: the Revised Nursing Work Index. Nurs Res. 2000;49(3):146-53. doi: https://doi. org/10.1097/00006199-200005000-00006

4. Aiken LH, Clarke SP, Sloane DM, Lake ET, Cheney T. Effects of hospital care environment on patient mortality and nurse outcomes. J Nurs Adm. 2008; 38(5): 223-9. doi: https://doi.org/10.1097/01.NNA.0000312773.42352.d7

5. Wei $H$, Sewell KA, Woody $G$, Rose MA. The state of the science of nurse work environments in the United States: a systematic review. Int J Nurs Sci. 2018:5(3):287-300. doi: https://doi.org/10.1016/j.ijnss.2018.04.010

6. Cho E, Sloane DM, Kim E-Y, Kim S, Choi M, Yoo IY, et al. Effects of nurse staffing, work environments, and education on patient mortality: an observational study. Int J Nurs Stud. 2015;52(2):535-42. doi: https://doi.org/10.1016/j. ijnurstu.2014.08.006

7. Oliveira JLC, Souza VS, Pereira ACS, Haddad MCFL, Marcon SS, Matsuda LM. Work environment and accreditation: analysis by mixed explanatory sequential method. Esc Anna Nery. 2018;22(4):e20170379. doi: https://doi. org/10.1590/2177-9465-EAN-2017-0379

8. You LM, Aiken LH, Sloane DM, Liu K, He GP, Hu Y, et al. Hospital nursing, care quality, and patient satisfaction: cross-sectional surveys of nurses and patients in hospitals in China and Europe. Int J Nurs Stud. 2013;50(2):154-61. doi: https://doi.org/10.1016/j.jinurstu.2012.05.003 
Magalhães AMM, Cunha DRMF, Moura GMSS, Urbanetto JS, Wegner W, Oliveira JLC

9. Coetzee, SK, Klopper HC, Ellis SM, Aiken LH. A tale of two systems - nurses practice environment, well being, perceived quality of care and patient safety in private and public hospitals in South Africa: a questionnaire survey. Int J Nurs Stud. 2013;50(2):162-73. doi: https://doi.org/10.1016/j.jinurstu.2012.11.002

10. Lee SE, Scott LD. Hospital nurses' work environment characteristics and patient safety outcomes: a literature review. West I Nurs Res. 2018;40(1):121-45. doi: https://doi.org/10.1177/0193945916666071

11. Oliveira PB, Spiri WC, Dell'Acqua MCQ, Mondini CCS. Comparison between the accredited and non-accredited public hospital working environments. Acta Paul Enferm. 2016;29(1):53-9. doi: https://doi.org/10.1590/1982-0194201600008

12. Gasparino RC, Guirardello EB, Aiken LH. Validation of the Brazilian version of the Nursing Work Index-Revised (B-NWI-R). J Clin Nurs. 2011;20(23-24):3494501. doi: https://doi.org/10.1111/j.1365-2702.2011.03776.x

13. Marcelino CF, Alves DFS, Gasparino RC, Guirardello EB. Validation of the Nursing Work Index-Revised among nursing aides and technicians. Acta Paul Enferm. 2014;27(4):305-10. doi: https://doi.org/10.1590/1982-0194201400052

14. Hospital de Clínicas de Porto Alegre (BR). Relatório Integrado de Gestão. Porto Alegre: HCPA; 2018 [citado 2019 nov 10]. Disponível em: https://www.hcpa. edu.br/downloads/relatorio_de_gestao_hcpa_2018.pdf

15. Panunto MR, Guirardello EB. Professional nursing practice: environment and emotional exhaustion among intensive care nurses. Rev Latino-Am Enfermagem. 2013;21(3):765-72. doi: https://doi.org/10.1590/50104-11692013000300016
16. Dorigan G, Guirardello EB. Nursing practice environment, satisfaction and safety climate: the nurses' perception. Acta Paul Enferm. 2017;30(2):129-35. doi: https://doi.org/10.1590/1982-0194201700021

17. Aiken LH, Sloane DM, Bruyneel L, et al. Association of nurse staffing and education with hospital mortality in 9 European countries: a retrospective observational study. Lancet. 2014; 383(9931):1824-30. doi: https://doi. org/10.1016/S0140-6736(13)62631-8

18. Alves, DFS, Guirardello EB. Nursing work environment, patient safety and quality of care in pediatric hospital. Rev Gaúcha Enferm. 2016;37(2):e58817. https:// doi.org/10.1590/1983-1447.2016.02.58817

19. Lake ET, Sanders J, Duan R, Riman KA, Schoenauer KM, Chen Y. A Meta-Analysis of the Associations Between the Nurse Work Environment in Hospitals and 4 Sets of Outcomes. Med Care. 2019;57(5):353-61. doi: https://doi.org/10.1097/ MLR.0000000000001109

\section{Acknowledgment:}

We thank the funding received from the National Council for Scientific and Technological Development - CNPq - Brasil- MCTIC/CNPq call No. 28/2018 - Universal. We also thank the Research Incentive Fund (Fundo de Incentivo à Pesquisa, FIPE) of the Porto Alegre Clinical Hospital (Hospital de Clinicas de Porto Alegre, HCPA).

\section{- Corresponding author:}

Ana Maria Müller de Magalhães

Email:amagalhaes@hcpa.edu.br

\section{Associate editor:}

Dagmar Elaine Kaiser 